Article

\title{
The 'Greening' of Christian Monasticism and the Future of Monastic Landscapes in North America
}

\author{
Jason M. Brown
}

Department of Humanities, Faculty of Environment, Simon Fraser University, Vancouver, BC V6B 5K3, Canada; jason.minton.brown@gmail.com

Received: 12 June 2019; Accepted: 11 July 2019; Published: 16 July 2019

\begin{abstract}
Christian monasticism has an ancient land-based foundation. The desert fathers and later reform movements appealed to the land for sustenance, spiritual metaphor, and as a marker of authentic monastic identity. Contemporary Roman Catholic monastics with this history in mind, have actively engaged environmental discourse in ways that draw from their respective monastic lineages, a process sociologist Stephen Ellingson calls 'bridging'. Though this study is of limited scope, this bridging between monastic lineages and environmental discourse could cautiously be identified with the broader phenomenon of the 'greening' of Christianity. Looking to the future, while the footprint of North American monastic communities is quite small, and their numbers are slowly declining, a variety of conservation-minded management schemes implemented since the 1990s by some communities suggests that the impact will remain for many decades to come.
\end{abstract}

Keywords: religion and ecology; spiritual ecology; greening of religion; environmental humanities; monasticism; history of monasticism; landscape

\section{Introduction}

When the monks of Our Lady of Guadalupe Abbey arrived at their new home in Carlton, Oregon, in 1955, they found a landscape quite different from the one their scout had purchased. All that remained of the lush Douglas fir forests were stumps and the previous owner had quite literally cut and run. Over the next several decades the monks slowly replanted the steep hillsides of their 1300 -acre sanctuary nestled in the foothills of the Coastal Range. Today, the monastery boasts an 800 -acre working forest with dozens of acres of restored Oregon White Oak savanna, one of the most rare and endangered ecosystems in Oregon.

The monks of Guadalupe Abbey's understanding of the land has also undergone transformation since their arrival. In the 1990s, under pressure from environmentally conscious members of their community, they hired a consulting forester who helped the monks envision and transition their forestry operation from a tree farm that maximized timber growth, to an ecosystem management approach that mimicked a natural forest while also providing timber revenue. Guadalupe Abbey is a unique place, but their turn toward more ecological approaches to stewardship and land management has been repeated many times over in the North American monastic landscape.

While there was once a time when monks sought a more complete fuga mundi-fleeing from the world-The Second Vatican Council (1962-1965) brought sweeping changes to Roman Catholic clerical and liturgical life. Many monastic communities have, as a result, gradually opened to the wider world, including the insights and convictions of what would become the environmental movement. There has been since the 1970s, but mostly since the 1990s, a slow but significant 'greening' of many religious institutions, who have incorporated the insights of environmental discourse on their own terms (Ellingson 2016). In this essay, I will argue that contemporary Catholic monastic communities in North America have consciously 'bridged', to use Bruce Ellingson's term, contemporary environmental 
discourse with their own monastic lineages. This trend can be cautiously identified as part of a wider 'greening' of Christianity, which has taken place over the last several decades. This bridging has resulted in more ecologically sustainable management practices and land tenure arrangements. So, while monasticism is generally in decline in North America, the unique monastic landscapes that these communities have lovingly cared for over many decades will persist long into the future.

While this study is not exhaustive, it is based on significant ethnographic research among contemporary monastic communities in the American West and Southwest. This essay also draws from publicly available scholarly and journalistic sources in order to show a wider diversity of perspectives in the North American context. Of course, women's monastic communities are also engaging these themes, but my work looks primarily at men's communities. ${ }^{1}$ The ethnographic case study in this essay is drawn from my firsthand ethnographic work and is based on semi-structured walking interviews with over 50 monastics. ${ }^{2}$

\section{The Land Based Context for Monasticism}

The purpose of the monastic life is to seek God. However, in seeking God, monastic communities have often sought some measure of separation from the busy social world. In fleeing to remote natural settings, monastics sought to be alone with God like Jesus of Nazareth who often prayed in the desert. This is not to say that historical monasticism is inherently environmentally conscious as we might think of it today, but simply to point out that monastic spirituality and institutional identity are deeply land-based.

The first wave of Christian monasticism gained momentum in the 4th century CE. Behind the more well-known Saint Anthony the Great (251-356 CE), an early Desert Father, were thousands of men and women who flocked to the Syrian and Egyptian deserts to live the life of contemplative silence. The desert was a spiritual ecology that taught the monks how to pray through its vast expanses and its harsh and dangerous conditions. Saint Jerome (347-420), an early Desert Father and translator remarked that 'the desert loves to strip bare', and this is precisely what these early monastics were trying to do spiritually. Biblical scholar Belden Lane writes that, "In desert and mountain wilderness, people discover liminal places suggesting thresholds between where they have been and where they are going" (Lane 1998). The desert was sensed as a space on the margins between this world and the next and represented a kind of spiritual battlefield.

As monasticism was institutionalized by the Roman Catholic Church and spread into Europe, monastic orders and communities continued to be founded in rural or semi-wilderness areas, both out of a desire to hold the world at a distance, and as an homage to their desert fore-parents. Saint Benedict in Italy and later reform movements such as the Cistercians ${ }^{3}$ often sought remote rural settings for their monastic communities.

Monastic cloisters often included spaces for vegetable gardens, domesticated animals, orchards, a cemetery, workshops, and accommodations for guests and pilgrims. However, no single cloister could be wholly self-sufficient. As historian Christopher Brooke has documented, the monastery cellarer, charged with keeping the monastery well stocked with supplies, often had to source items such as wheat, beans, milk, butter, cheese, fish, wool, pig skin for parchment, timber, and stone for building from the surrounding countryside. Monasteries also needed access to vineyards for wine, orchards for fruit, flowers for the altar, and beeswax for candles. The monastic community was a highly

1 See (McFarland Taylor 2009). As Sara McFarland Taylor points out, women's monastic communities are deeply engaged in bridging environmental discourse with their own monastic lineages. In fact, she points out that in some cases, they are going a step further by engaging in what Ellingson and McFarland Taylor call 'bricolage', the intentional mixing and combining of two distinct traditions in the creation of a third, or hybrid, tradition.

2 This essay is a revised version of a chapter in my PhD dissertation, published in 2017 at the University of British Columbia.

3 A variant of the Cistercians are now called Trappists, from the French community located in Trappé, France, now belonging to the Order of Cistercians of the Strict Observance (OCSO). 
disciplined, hierarchical institution - a major social and political actor whose land-base was embedded within the feudal or manorial tenure systems that pervaded Europe during that period (Brooke 2003). ${ }^{4}$

Monastic communities were also imagined as liminal spaces between heaven and earth with the cloister garden at its center harkening back to the Garden of Eden. The cloister took on the tension between body and soul, earth and heaven, and the biblical land-based motifs of the paradise-garden and the desert-wilderness that are the setting of the messianic hopes for the Israelites. Historian of monastic architecture Megan Cassidy-Welch has written of monastic sacred space, noting that, "within the cloister, spaces of theological abstraction have been anchored to the earth" (Cassidy-Welch 2001, p. 69). The cloister garden for example was a kind of axis mundi representing the idealized Garden of Eden in and among the desert wilderness of the world.

There was also a recurring sense in monastic reforms that in order to get back to the purity of the monastic movement, a community should seek out remote outposts that test the limits of comfort and safety. Historian Ellen Arnold's study of a Carolingian-era Benedictine monastery complex called Stavelot-Malmedy shows just how important land was to the livelihoods and spiritual narratives of this monastic community. Stavelot-Malmedy was located in the forested Ardennes region of Belgium and thrived between the 7th and 9th centuries. Saint Remaclus (?-671) founded the monastery in $650 \mathrm{CE}$ with a group of fellow monks. In their written history, Stavelot-Malmedy is set in a rugged wilderness. With land donated by Sigibert III, the monastic charter says, "In our forest called the Ardennes, in an empty space of solitude" the forest was a place "in which a throng of wild animals springs forth" that was "confined by mountains," "impeded by swamp", and whose local population was "not fully established", and "bound up in idolatry" (Arnold 2012, p. 34). As Arnold shows in her study, the Ardennes had in fact been cultivated and occupied for many hundreds of years prior and was not excessively far removed from major transit corridors. The monastic founders' suggestion that the area was wild and dangerous appealed to their monastic heritage of fleeing the world for the desert wilds and thus tended to exaggerate the remoteness, sparseness of the population, and presence of danger. She writes:

Throughout the centuries, monks of the Ardennes developed the idea of the forest as a wild and dangerous landscape because it tied them to their religious heritage. But they had established their monasteries in a landscape that had long been full of people, and they were active participants in the regions social and agricultural structures. Thus, the monks not only had to define themselves in relation to the wild; they also had to define themselves in relation to local people and the domesticated landscape. To do this, they told stories of how the power of the saints and of God allowed the monks to transform the wilderness into a beautiful and controllable landscape. They then in turn, used this calm and pastoral view of the forest to represent rebirth, tranquility, and the fertility of both land and soul (Arnold 2012, p. 28).

Land was not just an integral part of their livelihoods but bound up with the monastic sense of self, history, and spirituality within a medieval agrarian view of place and landscape.

While medieval monasteries enjoyed a very large land base in Europe, the Protestant Reformation, beginning in the 16th century, and the French Revolution in the 18th century reduced Benedictine and Cistercian landholdings considerably, especially in England and France. These upheavals coincided with the broader dissolution of the feudal land systems throughout much of Europe (Horn 1973; Rippinger OSB 1990; Peters 2015). While monasticism did undergo a modest revival in the 19th century, it would never again reach the extent and influence it had during the feudal/manorial age and prior to the advent of the Mendicant orders of the late 12th and early 13th centuries. Debates about monasticism's environmental impact on feudal landscapes are ongoing (Bartlett 1993; Oram 2008;

4 While there is no official estimate of the historical extent of monastic landholdings, some have guessed that monastic tenure encompassed at least 50\% of some regions throughout Europe (Josep-Maria Mallarach, pers. Comm). 
Alberth 2012; Arnold 2012), but what is clear is that land provided a context both for monastic subsistence and spirituality.

As Mallarach and Papayannis (2007), Mallarach et al. (2012), and Mallarach et al. (2014) point out, a number of historical monasteries and hermitages in Europe have become the basis for protected areas. Moreover, many monasteries still in operation have adopted ecologically minded management practices and outlooks (Mallarach et al. 2014). For example, the Camaldoli Hermitage, which founded in 1024 by Romuald (951-1025). When Romuald arrived, he set his monks to planting trees to ensure a steady supply of wood. With a larger monastery at the base of the mountain and a cluster of hermitages up higher, Camaldoli has become an exemplary case of successful pre-modern forestry practices. It even served to inform the modern codification of the Italian Forestry Code during the 19th century (Pungetti et al. 2012). Today, the Hermitage, which is still in use, is the one of the longest continuously occupied monasteries in Europe. After World War II, it became part of the Casentine National Park, which encompasses 36,000 hectares, and is one of the largest national parks in Europe (Pungetti et al. 2012).

\section{The Greening of Religion Controversy}

In 1967, historian of technology Lynn White, Jr. levelled a controversial critique of Christianity's role in the environmental crisis (White 1967). White was certainly not the first to criticize Christianity or point out its penchant for ecological harm, but the publication of his piece in the journal Science gave the piece enough exposure to create a broader conversation among Western academics. White, himself a Presbyterian, claimed that through the biblical injunction to dominate the earth found in Genesis chapter one, Western Christianity had become "the most anthropocentric religion the world has ever seen," and Western technology and science thus had followed suit (White 1967, p. 1205).

Since White's article, there have been a great many attempts to respond to White's thesis, especially among Christians. The fields of religion and ecology, religion and nature, and spiritual ecology have sought to address the diverse ways in which religion contributes to environmental problems and solutions and to encourage a kind of 're-enchantment' of the natural world (Sponsel 2012; Vaughan Lee 2013). During the late 1990s and 2000s, then professors at Harvard, Mary Evelyn Tucker and John Grim organized a series of conferences on world religions and ecology, which included hundreds of scholars and practitioners from the world religions. The proceedings from that series were later published as a series called Religions of the World and Ecology and summarized in their recent book Ecology and Religion (Grim and Tucker 2014).

Sociologist Stephen Ellingson has shown that despite White and others early criticisms, the religions were late to the environmental movement. This is partly because they often chose to engage in what Ellingson calls "bridging" between religious and environmental values and discourse (Ellingson 2016). This means that religious environmental organizations, churches, or religious orders are engaging their religious traditions in light of environmental problems and finding ways to talk about them in their own idiom. Ellingson notes that while Christianity may have been late to the environmental movement, there are now almost 100 religious environmental organizations in existence today (Ellingson 2016). This is not to say that all self-identified Christians have become models of ecological sustainability, but that the language of environmentalism is finding expression in Christian categories and framings such as stewardship, sacramentalism and prophetic justice.

Before I discuss the contours of monastic environmental bridging, it is important to briefly point out that not all scholars agree that there has even been any significant greening of religion in general and Christianity in particular. While there has certainly been a surge of conversations surrounding the environment in Christian circles, some scholars suggest that we have not yet seen a measurable shift in pro-environmental behaviors among religious people and particularly Christians in the United States (Clements et al. 2014; Taylor et al. 2016). Religion and nature scholar Bron Taylor even goes a step further in a recent essay, claiming that Christianity is more likely to be a hindrance to the environmental movement than a partner (Taylor 2019). Luckily, in this essay, I am not seeking to adjudicate once and for all the phenomenon of greening among all self-identified Christians or even 
all monastic institutions. However, I do feel confident speaking of a general shift among North American Catholic men's monastic communities toward more ecologically minded theology and land management practices, which I will now address.

\section{Monasticism and Environmental Discourse}

Beginning in the 1960s, but especially during the 1990s, monastic communities in North America have actively engaged with environmental discourse that call for minimizing pollution, protecting wilderness, and managing agricultural lands sustainably. Trappist monk and writer Thomas Merton is something of the unofficial nature writer of the contemporary monastic tradition. Merton was a gifted poet and writer, and his writings ushered in a surge of post-WWII monastic vocations. Before his death in 1967, Merton joined the Wilderness Society and saw a strong connection between the monastic desire to seek God within and the setting of monasteries among wild and rural landscapes. When he entered Gethsemani Abbey in 1941, Merton fell in love with the hilly wooded landscape. In 1967, Merton was even permitted to move full time into a small hermitage on the Abbey property, the first of his order to do so. At the heritage, Merton wrote beautiful poetry, weather reports, and spiritual prose that masterfully described his wooded surroundings. He also began to re-imagine the role for monks in the budding environmental movement through his brief correspondences with environmental writer Rachel Carson. He wrote:

If the monk is a man whose whole life is built around a deeply religious appreciation of his call to wilderness and paradise, and thereby to a special kind of kinship with God's creatures in the new creation ... then we might suggest that the monk, of all people, should be concerned with staying in the 'wilderness' and helping to keep it a true 'wilderness and paradise.' The monk should be anxious to preserve the wilderness in order to share it with those who need to come out from the cities and remember what it is like to be under trees and to climb mountains.

(Merton 1967, p. 89)

This last phrase is very much reminiscent of 19th century conservationist John Muir, who saw wilderness not as a spiritual battlefield, but a paradise, a sanctuary. What Merton is doing here is carrying forward the biblical and monastic motifs of the wilderness and the garden, the eschatological hope of the monk to return to his true nature before the fall. However, by embracing the logic of the American environmental movement, rather than converting the wilderness into a paradise through agricultural work as his monastic ancestors sought, wilderness is envisioned as paradise, a move also made by Henry David Thoreau in his essay Walden (Brown 2017).

This bridging work between monastic history and spirituality on the one hand and the environmental movement on the other trickled down into monastic communities throughout North America. Coinciding with Merton's later writings and the Vatican II council, the monastic movement in North America sought to rediscover its spiritual roots. Unsurprisingly, this also meant rediscovering monasticism's relationship to land. Benedictine historian Joel Rippinger OSB writes that the post-Vatican II-era monastic renewal was:

accompanied by the Benedictine equivalent of the experiments in communal and rustic 'return to nature' that were so much a part of the American counterculture of the time, and the results of this were the closure of many community buildings and a monastic diaspora of some who wanted to live in smaller communities in cabins or rustic retreats (Rippinger OSB 1990, p. 176).

Just as the many monastic movements before them had done, and just as strands of America's back-to-the-land movement were trying out, many monastic communities attempted to return to a simpler way of living, often with an emphasis on being close to the land. 
One community that exemplified this movement was Christ in the Desert Abbey located in Abiquiu, New Mexico. The community was founded by three monks from Mount Savior Benedictine Abbey in upstate New York. The monks were inspired by the 1960s move toward greater simplicity, and a more solitary land-based, desert monasticism (Graña 2006). The monastery now boasts a completely self-reliant solar panel array, which is one of the largest in New Mexico, straw bale-insulated green buildings, water conservation infrastructure, and large vegetable gardens. Similar to many monastic communities who have an internet presence, their website embeds the contemporary value of ecological sustainability within the Benedictine vocation of contemplative prayer: "The Benedictine charism, notable for simplicity, humility, stability, and hospitality, is especially well suited to sustainable stewardship of the natural environment." ${ }^{\prime 5}$

In the 1980s, Terrance Kardong OSB, a Benedictine monk, published an article entitled "Monks and the Land", which celebrates the Benedictine land-based heritage and laments the rise of industrial farming and its contribution to the decline in monastic land-based industries and general stewardship practices. He also suggested that there are few monasteries left in the US that are fully managing their own land or doing so sustainably. Citing the agrarian writer Wendell Berry, Kardong called for a return to the traditional land-based Benedictine values of stability, work, and stewardship, just as reformers before him have done. He admonished, "A monastery is not nowhere but somewhere. We must take good care of that somewhere. To be a monk is not to practice an ethereal spirituality that treats place as irrelevant" (Kardong 1983, p. 144). Drawing on his monastic roots, Kardong sounds a warning that Benedictine monasticism has strayed too far from its land-based foundations and needs an agrarian revival, which in many ways paved the way for many of the changes that took place in the 1990s.

Since the 1990s, many Trappist monasteries have also engaged with the contemporary environmental movement, both theologically and practically. One celebrated case involves a community of Trappist monks who actively sought out consultation in order to improve their land management practices in line with contemporary environmental discourse: Holy Cross Trappist Abbey, located in Clarke County, Virginia. In 2007, they sought the help of students and faculty at the University of Michigan's Natural Resource Management program to conduct a thorough assessment of the community's practices. The team published a report, which includes a detailed environmental assessment of the 1200-acre property (Buckner et al. 2010).

The study begins in familiar territory, by citing foundational Benedictine values that harmonize with contemporary environmental discourse around stewardship, care, and connection to place. For example, this quotation from the 2005 Cistercian Constitution Section 27A "The brothers are to be concerned about conservation of the environment and to manage natural resources prudently" is seen as ample support for engaging in environmentally friendly management and practices. The introduction cites the Benedictine ethos of 'Work and Prayer', and the Cistercian admonition to be 'lovers of the place' as further moral impetus to be better stewards of the land.

The study presents a detailed assessment of the 'sustainability' of eight domains: land use, energy, water, solid waste, toxics, economies, food, and buildings. Their conclusions suggested that while the monks love their land, the monastery was far from a model of ecological sustainability. They found that monoculture farming practices were degrading local water and soil quality, that cattle grazing was increasing soil erosion, and that invasive plants were threatening local biodiversity. They found a poor native-habitat-to-developed-spaces ratio and an undeveloped trail system. Energy production was inefficient, and $\mathrm{CO}_{2}$ emissions were higher than local averages. They used more water but generated less waste than the average North American. In addition, the monastery used over 100 harmful chemicals and had asbestos and lead paint in structures and mold growing in several places. The baking

5 Christ in the Desert Monastery. Available Online: https://christdesert.org/about/sustainable-stewardship/ (accessed on 12 June 2019). 
of fruitcakes, one of their livelihood enterprises, generated significant carbon emissions, and their food was sourced through corporate, non-organic distributors. The community had a lot of work to do.

Since the report, the community has set to work on both ensuring that the community remains on the land and that their management practices are in greater harmony with the principles of ecological sustainability. The community was recently featured in National Geographic for their efforts, which included establishing an 80-acre green cemetery, where natural burials occur, and ashes can be spread. While they have not returned to farming the land themselves, due to dwindling vocations, one of their tenants has begun farming 200 acres organically, and they have fenced off streams where cattle used to graze to reduce contamination and erosion (Bruno 2017). The community has also created a 'conservation easement' with a local land trust, which ensures the property will remain intact and undeveloped in perpetuity. Conservation easements, an increasingly popular tool in private conservation efforts, are essentially legally binding agreements wherein a third party purchases the rights to develop the property in perpetuity. The third party outlines what is allowable and not allowable on the land based on conservation and restoration priorities and is tasked with monitoring the easements in perpetuity. As we will see, this strategy promises to have a lasting impact on the future of monastic landscapes.

Another noteworthy 'bridging' event occurred in 2008 at the Abbey of Our Lady of Gethsemani, Thomas Merton's monastery. The Abbey held a conference titled 'Monasticism and the Environment' (Mitchell and Skudlarek 2010). This wide-ranging interfaith conference in which Buddhist and Catholic monks participated, argued for a shift toward a "green" monasticism, whether Buddhist or Catholic, through theological and spiritual interpretation of their respective traditions and wiser use of resources and land bases. The talks each addressed some aspect of bridging between monasticism and environmental discourse, pointing to the Benedictine work ethic, the sacramental theology of Catholicism, or the examples of saints, such as Saint Francis of Assisi.

\section{An Ethnographic Case Study in Land-Based Monasticism}

In April of 2016, I spent approximately 10 days at Our Lady of Guadalupe Trappist Abbey as an ethnographic researcher. The Abbey is a Trappist monastery that was founded in 1955 by monks from Pecos, New Mexico, who had abandoned the site, because it was difficult to farm. The monastery is located is a small valley between two ridges that run north and south in the semi-arid western foothills of the Oregon Coastal Range. It is surrounded by rural properties on all sides, an increasing amount of which are devoted to wine grapes. The property is home to mule deer, bobcats, and many migratory and resident birds, and the large retreatant pond shelters carp and bullfrogs.

Once they arrived, the monks continued growing grain in the bottomlands and raised sheep and cattle on the hillsides until the farm closed in the mid-1960s due to shifts in agricultural policy that made small farming untenable. They eventually sold their livestock and leased their farmland to a local farmer, putting all of their energy into other industries, such as a carpentry shop, which manufactured church pews and other furniture, and a book bindery that sourced clients from local universities. In the 1980s, the Abbey added a fruitcake bakery and, in the 1990s, a wine storage and labeling facility. The approximately 300 acres of leased farmland grew a variety of commodities such as grass seed until 2016, when the monks decided to start a contract with a leasee, who has planted the land with hazelnut-a common commodity crop in Western Oregon.

Starting in 1967 with a Christmas tree operation, the monks began actively managing about 880 acres for timber production, planting mostly Douglas fir, but also experimenting with Ponderosa pine (Pinus ponderosa), Knobcone pine (Pinus attenuata), hybrid poplar (Sp. populus), and Leland cypress (Cupressus leylandii). In the 1980s, active harvesting was begun by a small crew of monks. The small monastic forestry crew planted, thinned, pruned, and harvested the trees themselves in small block cuts and replanted them in tightly spaced monocrop tree plantations. Plantings were not concerned with privileging native species, and management was designed to maximize the production of timber resources. 
The monks of Guadalupe inherited a classically Trappist agrarian theology, which imagined human beings working cooperation with God to improve the earth through cultivation. They were proud stewards of the land and saw the forest as a kind of 'tree-farm' for the production of products and revenue. As the monks grew older and vocations continued to shrink throughout the 1970s, they began to reach out for help with managing their land. One landmark came in the late 1980s, when a heavy-handed clear cut near a favored picnic area angered several of the monks who were beginning to advocate a more environmental approach that was consistent with their monastic values and the need to generate some revenue from the forest. It was decided to discern a new forest management strategy and to hire a professional forester to manage the forest with the help of a small monastery forestry crew. In 1995, this forester conducted an inventory of the property and developed a management plan that would balance spiritual values and ecological health with the need to generate revenue.

Since 1995, under the monks' direction, the manager has transitioned the property to an ecosystem-based management approach, obtaining Forest Stewardship Council (FSC) certification, a third-party certification that ensures that ecological principles are used in management and harvest. In practice, this means there has been a decrease in patch cut size to no more than two acres and the increased use of commercial thinning as a harvesting technique, in order to diversify the forests' age and structural diversity. Harvest areas leave more standing dead trees and wildlife trees and more downed trees for woody debris and has focused on clearing areas around shaded white oak and madrone trees to increase native tree species diversity and more bird habitat.

In 2010, they also began aggressively managing for invasive species such as False Broom (Brachypodium sylvaticum), Scots Broom (Cytisus scoparius), and English Hawthorn (Crataegus laevigata) and have designated a small 80 -acre section of forest as a future old growth forest area set aside from thinning and commercial harvest.

The forest manager was also instrumental in enrolling the property into a conservation easement program funded by the Bonneville Power Administration, a hydroelectric dam company that has been legally obligated to purchase conservation easements for habitat restoration in and around the Columbia River because of the land it flooded by building their dams. After a lengthy process and assessment, the monastery entered into an agreement to keep the property undeveloped and to continue to manage the forest sustainably.

In addition, the easement qualified the monastery for additional funds that were used to restore areas of Oregon White Oak (Quercus garryana) savanna on the property. According to the Oregon Conservation Strategy, Oregon White Oak savanna is an endangered ecosystem, with less than 5\% of its historical range remaining. In the past, the white oak was left to be overgrown or cleared to make way for more Douglas fir and sold as firewood.

The climate of the area before European settlement was adapted to White Oak, and Kalapuyan Peoples used fire to clear the area of trees to maintain open hunting grounds. Without fire, the Douglas fir trees outgrow the White oaks, eventually shading them out completely. By harvesting all the trees except the White oaks, a stand replacing fire is mimicked, and the oaks return to health and vigor, reproducing naturally.

From its early agrarian roots through its industrial tree farm planting to its contemporary context as an ecological working forest, Our Lady of Guadalupe has undergone significant changes in its approach to land and forest management. For example, as we walked by a particularly straight row of Douglas fir trees, a Brother related to me a memory of the former forest manager monk:

Father Romaine, when he was with us, he was one of the main planters and he walked by here once and said, 'this is what some people contemptuously call a tree farm', at which he took great umbrage at because he thought it was a forest. But if you look at it compared to the other parts of the forest it is kind of a tree farm.

The monk I was speaking with, who had been raised with a strong environmental consciousness, felt that there was, in fact, a difference between a naturally generated forest and an intensive geometric, 
monoculture plantation. For Father Romaine, however, steeped in the agrarian approach to forestry, where trees were essentially crops, the distinction was belittling of the work he had done to reestablish the forest from the degraded state it was in when they arrived in the 1950s.

The monastery now sees itself as a kind of sanctuary to monks and visitors alike. This is because one condition of the conservation easement allows public access for quiet recreational hiking. In fact, the monastery is now one of the largest intact forest areas in Yamhill County, Oregon, which is primarily agricultural and has very few protected areas. This fact was seen as part of the monastery's ministry to the wider world. As another monk related:

To me the only purpose of a monastery is to be a sanctuary. And certainly there's been times in history where there's been even more need, but for us today I think there's an intense need for sanctuary and that's what we have to offer.

Embedded in Western Oregon, which embodies a strong tension between environmentalists and loggers, the monastery has been influenced by elements of both. While it is rooted in the Trappist agrarian sensibility, the community has since enthusiastically adopted a program of ecological restoration, invasive species removal, and forest certification. The paradigm of forest management is "ecological forestry", with an emphasis on restoring native species and endangered ecosystems and increasing the forest's structural and age diversity - a major shift from its former days as a production-oriented tree farm. And while Trappists are known for their hard work, they now primarily see the forest as a sanctuary rather than a crop.

\section{The Future of Monastic Landscapes}

According to the Center for Applied Research in the Apostolate, in 1970, there were approximately 41,886 male members of Catholic religious communities. By 2015, that number had dropped to 17,791-that is a loss of over 500 per year (Palacios et al. 2015). It is increasingly common that the average age at a men's monastery will be in the 70 s or even 80 s.

However, while vocations to monastic communities are, generally speaking, declining, interest in monastic and contemplative spirituality is being explored, rediscovered, and repurposed by an ever growing and wider variety of spiritual, social, political, and environmental movements. In the spiritual realm especially, retreats and monastic spirituality are increasingly common at monasteries in North America. Thus, between the declining numbers of monks making lifelong vows to their communities and the increasing interest in their landscapes as spiritual refuges, it is not certain what the future holds for land-based monasticism in North America.

As North American monasteries have declined and the economy has shifted away from agriculture, many monasteries have had to make adjustments to land tenure arrangements: selling off pieces of land, leasing farmland to neighboring operations or other schemes. ${ }^{6}$ Saint Procopius's Abbey was a Benedictine monastic community located in rural Illinois until it became economically unviable in the 1960s. The monks originally managed some 365 acres, housing over 30 monks. The property included the farm - which raised cattle, chickens, turkeys, hogs, beehives, a peach orchard, and a large garden-a boarding school, a small college, and an orphanage (Fletcher 2015).

Theologian Christine Fletcher suggests that while the monks felt a strong agrarian attachment to their land and their vocation as farmers, it was finally agreed that they had reached a threshold. The monastery decided rather than sell the land outright, they would collaborate with a developer to create a "sustainable community" called 'Green Trails', which would devote $40 \%$ of total land (135 acres) apart from the monastery proper, to recreation, walking trails, lakes, and park areas. The author sees this compromise as an example of the uniquely Benedictine values being applied to a difficult

6 Saint Martin's Abbey and Mount Angel Abbey are both Benedictine monasteries who maintained self-sustaining farms until the early 1960s. They have since shifted focus to other apostolates. See (Yocom 1985; Scott 1996). 
land-based problem and a solution that uniquely blended the monks' attachment to the land with the pragmatic needs of a changing monastic community and a growing environmental consciousness. Fletcher writes, "The difference Benedictine stewardship makes is clearly visible in Green Trails in the large amount of common areas for people to gather, and in the mix of housing: large and small single-family units, low-rise condominiums, and high-rise apartment buildings" (Fletcher 2015, p. 190). Fletcher argues that this project was "ecologically sustainable" but within the Benedictine frame of human use and occupancy of the land: "Green Trails is an example of Benedictine stewardship of the environment in a situation when the agricultural life envisioned by Benedict could no longer be sustained" (Fletcher 2015, p. 191). In this way the monastery continues its apostolate and its formation of monks and has written its values into the landscape that now surrounds the monastery and its college; a legacy that will continue even if the monastery eventually closes.

Inevitably, some monasteries have been forced to close. However, arrangements with the buyer of the property and the Catholic diocese have ensured that the monks' footprint will survive long after they are gone. The Trappist Abbey of Our Lady of the Holy Trinity in Huntsville, Utah, was founded in 1947. The monks made a living by growing grain, raising cattle, keeping bees, and baking bread. The land, perched in a mountain valley surrounded by the Wasatch Mountains, has a beautiful rural character, boasts hundreds of trees planted by the monks, and harbors a spring that is valuable to the Huntsville water supply. In 2016, the land was officially sold to a private resident of Huntsville, who is working with a local land trust to ensure that the property is preserved through a conservation easement that will restrict development of the site in perpetuity and ensure the sustainable management of the property by future leases. A small footprint near the Abbey church will be gifted to the Roman Catholic Diocese for the construction of a parish church. The process has been facilitated by a team of Utah State University regional planning students to ensure that the land will continue to reflect the monks' contribution to the land. This case, though unfortunate, shows how integral land is to the Benedictine/Trappist lineage and how beloved the monks were in the community, which is largely populated by Mormons (LDS) (Utah State University 2015; Shaw 2017).

The conservation easement is an increasingly popular private conservation tool outside of traditionally designated protected areas. Active monastic communities, such as those discussed in this essay, have used them to gain revenue while improving their land management regimes, and even to restore habitats. Yet, as we have seen, even monasteries who did not implement conservation easements during their tenure as active monasteries have garnered support for their use once they have closed, as is the case in Utah.

\section{Conclusions}

In this essay, I have shown that Catholic monasticism is deeply intertwined with the land. During the last 50 years or so, monasticism in North America has creatively engaged with environmental discourse in their attempts to improve land and resource management. I have argued that monastics actively bridge their own lineages with environmental discourse. This has resulted in many changes in monastic land management and an increasing awareness of environmental values. These values have, in some cases, been institutionalized through conservation easements, which permanently protect the land, even if the monastery closes in the future, which as we have seen is a very real possibility for some dwindling communities. Thus while the monastic landscape may never reach the extent of influence it once wielded in the middle ages, it is clear that land-based monastic communities will continue their influence on the land and the communities in which they have been founded for many centuries to come.

Funding: This research was funded as part of my dissertation Research at the University of British Columbia, Vancouver. I received a four year International Student Fellowship from the University of British Columbia. The Ethics review of this project was conducted through the UBC Behavioral Research Ethics Board, under the project title "Dwelling in the Wilderness," Certificate Number H14-02005.

Conflicts of Interest: The author declares no conflicts of interest. 


\section{References}

Alberth, John. 2012. An Environmental History of the Middle Ages. New York: Routledge.

Arnold, Ellen F. 2012. Negotiating the Landscape: Environment and Monastic Identity in the Medieval Ardennes. Philadelphia: University of Pennsylvania Press.

Bartlett, Robert. 1993. The Making of Europe: Conquest, Colonization and Cultural Change. Princeton: Princeton University Press.

Brooke, Christopher. 2003. The Age of the Cloister: The Story of Monastic Life in the Middle Ages. Santa Monica: Hidden Spring Press.

Brown, Jason. 2017. Merton, Wildness, and the Sacramental Power of Place. Merton Annual 29: 80-89.

Bruno, Debra. 2017. These Monks Saved Their Abbey by Protecting the Earth. National Geographic. Available online: http://news.nationalgeographic.com/2017/04/monks-sustainable-holy-cross-abbey/ (accessed on 23 May 2017).

Buckner, Kathryn, Craig Cammarata, Charlotte Coultrap-Bagg, Alexander Linkow, Jessica Neafsey, and Christopher Stratman. 2010. Holy Cross Abbey: Reinhabiting Place. Ann Arbor: School of Natural Resources and Environment, University of Michigan.

Cassidy-Welch, Megan. 2001. Monastic Spaces and their Meanings: Thirteenth-Century English Cistercian Monasteries. Turnhout: Brepols.

Clements, John M., Chenyang Xiao, and Aaron M. McCright. 2014. An Examination of the "Greening of Christianity" Thesis among Americans, 1993-2010. Journal for the Scientific Study of Religion 53: 373-91. [CrossRef]

Ellingson, Stephen. 2016. To Care for Creation: The emergence of the Religious Environmental Movement. Chicago: University of Chicago Press.

Fletcher, Christine. 2015. The Border between Wilderness and Garden: Cultivating a Benedictine Spirituality of the Land. In An Unexpected Wilderness: Christianity and the Natural World. Edited by Collen Mary Carpenter. Maryknoll: Orbis Books, pp. 182-92.

Graña, Mari. 2006. Brothers of the Desert: The Story of the Monastery of Christ in the Desert. Santa Fe: Sunstone Press. Grim, John, and Mary Evelyn Tucker. 2014. Ecology and Religion. New York: Island Press.

Horn, Walter. 1973. On the Origins of the Medieval Cloister. Gesta 12: 13-52. [CrossRef]

Kardong, Terrance. 1983. Monks and the Land. Cistercian Studies 18: 135-48.

Lane, Belden C. 1998. The Solace of Fierce Landscapes: Exploring Desert and Mountain Spirituality. Oxford: Oxford University Press.

Mallarach, Josep-Maria, and Thymio Papayannis, eds. 2007. Protected Areas and Spirituality. Paper presented at the First Workshop of the Delos Initiative, Montserrat, Spain, November 23-26; 2007, Gland: IUCN, Montserrat: Publicacions de l'Abadia de Montserrat.

Mallarach, Josep-Maria, Thymio Papayannis, and Rauno Väisänen, eds. 2012. The Diversity of Sacred Lands in Europe: Proceedings of the Third Workshop of the Delos Initiative-Inari/Aanaar 2010. Gland: IUCN, Vantaa: Metsähallitus Natural Heritage Services.

Mallarach, Josep-Maria, Josep Corcó, and Thymio Papayannis. 2014. Christian Monastic Communities Living in Harmony with the Environment: An Overview of Positive Trends and Best Practices. Studia Monastica 56: 353-91.

McFarland Taylor, Sara. 2009. Green Sisters: A Spiritual Ecology. Cambridge: Harvard University Press.

Merton, Thomas. 1967. Wilderness and Paradise: Two Recent Studies. Cistercian Studies Quarterly 2: 83-89.

Mitchell, Donald, and William Skudlarek, eds. 2010. Green Monasticism: A Buddhist-Catholic Response to an Environmental Calamity. New York: Lantern Books.

Oram, Richard D. 2008. Holy Frontiersmen? Twelfth-and Early Thirteenth-Century Monastic Colonization and Socio-Economic Change in Poland and Scotland. In The Northern World: Britain and Poland-Lithuania: Contact and Comparison from the Middle Ages to 1795. Edited by Richard Unger and Jakub Basista. Leiden: BRILL, pp. 103-22.

Palacios, Santiago Sordo, Thomas P. Gaunt, and Mary L. Gautier. 2015. Population Trends among Religious Institutes of Men. Washington: Georgetown University, Center for Applied Research in the Apostolate.

Peters, Greg. 2015. The Story of Monasticism: Retrieving an Ancient Tradition for Contemporary Spirituality. Grand Rapids: Baker Publishing. 
Pungetti, Gloria, Father Peter Hughes, and Oliver Rackham. 2012. Ecological and Spiritual Values of Landscape: A Reciprocal Heritage and Custody. In Sacred Species and Sites. Advances in Biocultural Conservation. Edited by Gloria Pungetti, Gonzalo Oviedo and Della Hooke. New York: Cambridge University Press, pp. 65-82.

Rippinger OSB, Joel. 1990. The Benedictine Order in the United States: An Interpretive History. Collegeville: Liturgical Press. Scott, John C. OSB. 1996. This Place Called Saint Martin's: 1895-1995: A Centennial History of Saint Martin's College and Abbey Lacey, Washington. Virginia Beach: The Donning Company Publishers.

Shaw, Mitch. 2017. Huntsville Man on a Mission to Preserve Monastery Open Space. Standard Examiner. Available online: http://www.standard.net/Local/2017/04/12/Huntsville-man-on-a-mission-to-preservemonastery-open-space (accessed on 23 May 2017).

Sponsel, Leslie. 2012. Spiritual Ecology: A Quiet Revolution. Santa Barbara: ABC-CLIO.

Taylor, Bron. 2019. Religion and Environmental Behavior (part one): World Religions and the Fate of the Earth. The Ecological Citizen 3: 71-79.

Taylor, Bron, Gretel Van Wieren, and Bernard Daley Zaleha. 2016. Lynn White Jr. and the greening-of-religion hypothesis. Conservation Biology 30: 1000-9. [CrossRef] [PubMed]

Utah State University. 2015. USU Students Present Options for Huntsville Monastery's Transition. Utah State Today. Available online: http://www05.usu.edu/today/?id=54448 (accessed on 23 May 2017).

White, Lynn, Jr. 1967. The Historical Roots of our Ecological Crisis. Science 155: 1203-7. [CrossRef] [PubMed] Vaughan Lee, Llewellyn. 2013. Spiritual Ecology: The Cry of the Earth. Point Reyes: The Golden Sufi Center. Yocom, Neil OSB, ed. 1985. Mount of Communion: Mount Angel Abbey: 1882-1982. Mount Angel: Mount Angel Abbey.

(C) 2019 by the author. Licensee MDPI, Basel, Switzerland. This article is an open access article distributed under the terms and conditions of the Creative Commons Attribution (CC BY) license (http://creativecommons.org/licenses/by/4.0/). 